\title{
K VPRAS̆ANJU IDENTITETE IN OTROŠTVA MARIJA KOGOJA
}

\author{
Ivan $\mathrm{K}$ l e m e n č i č (Ljubljana)
}

V Kogojevi biografiji je dolgo časa ostalo odprto vprašanje identitete, tj. zamenjave imena Julij za bratovo Marij in s tem rojstnih letnic, ${ }^{1}$ vprašanje, za katero smo vedeli, da še čaka podrobne obdelave. Nedavno je to delo temeljito opravil Pavle Merkù iz Trsta, ki je na kraju samem zbral bogato dokumentacijo ter izčrpno in $\mathrm{s}$ pomočjo faksimilov $\mathrm{z}$ vso razvidnostjo osvetlil celotno vprašanje. ${ }^{2} \mathrm{~V}$ svoji razpravi je sklepal, da je $\mathrm{v}$ resnici prišlo do zamenjave imen in tudi rojstnih letnic. Tako je bil nam znani skladatelj Marij Kogoj resda rojen 27. IV. 1895, a je dokumentirano umrl kot osemmesečni dojenček 31. I. 1896. Takrat naj bi po Merkùjevem mnenju dali njegovo ime starejšemu bratu Juliju, ki se je rodil 20. IX. 1892. Zato je pravi, nam znani skladatelj lahko le Julij Kogoj, rojen v Trstu 20. IX. 1892. Temu je Merkù ob novi rojstni letnici obdržal staro, že poznano ime: torej skladatelj je Marij Kogoj, rojen 20. IX. 1892.3

Toda kot je bilo to vprašanje samo zase smiselno rešeno, nastanejo težave in dvomi, ko skušamo to novo rojstno letnico Marija Kogoja uskladiti z njegovimi drugimi življenjskimi podatki, zlasti $\mathrm{s}$ tistimi o šolanju. Pri tem se namreč izkaže, da se je dosedanje rojstno leto 1895 ujemalo s časom skladateljevega šolanja, medtem ko se leto 1892, po katerem je

${ }^{1}$ Kogoj se je v skladbah, nastalih po začetku bolezni 1.1932 podpisoval "(J.) [tj. Julij] Marij Kogoj«. O vprašanju zamenjave imena $\mathrm{z}$ bratom so pisali Leban K., v Kanal ob Soči so pripeljali tri sirote, Tovariš 26. IV. 1956, str. 458 in 470 , Jež J., Marij Kogoj - skladateljeva mladostna leta (pismena naloga za strokovni izpit), Ljubljana 1957 in tudi Pilon V., Spomin na Kogoja in na goriška leta, Bori I/1955, 235-37 ter isti, Na robu, Ljubljana 1965, 61. Pilon je v svoji knjigi omenjal: "Glede njegovih staršev si nisem nikdar na jasnem, saj je sam govoril o dvomljivi letnici svojega rojstva in se ovijal $\mathrm{v}$ neke vrste romantične legende. Njegova nenavadna, eksotična zunanjost... je to skrivnost še stopnjevala." Kogojeva učiteljica Karolina Leban je za zamenjavo imen dobro vedela, Jakob Jež pa je po njej domneval, da bi lahko prišlo $\mathrm{z}$ zamenjavo imen tudi do zamenjave rojstnih letnic; menil je, da bi bilo mogoče to vprašanje še raziskati, vendar se sam raziskave ni lotil.

${ }^{2}$ Merkù P., Identiteta in otroštvo Marija Kogoja, Muzikološki zbornik XII/1976.

${ }^{3}$ Merkù P., ib. 
Marij Kogoj nenadoma starejši za 2 leti, 4 mesece in 24 dni, ne ujema. Če pa bi šel skladatelj vendarle toliko starejši v šolo, bi bilo treba vsaj dobro poznati okoliščine in kakorkoli utemeljiti to njegovo precej nadpovprečno starost $\mathrm{v}$ šoli. Poleg tega sem uspel zbrati še nekatere podatke, ki bi utegnili doslej ugotovljeno skladateljevo identiteto in z njo rojstno letnico 1892 izpodbijati.

Ko se sprašujemo o starosti Marija Kogoja $v$ šoli, so nam dokumentirano na voljo podatki iz gimnazije in visoke šole. To so spričevala iz k. k. Staatsgymnasium v Gorici in iz študija na k. k. Akademie für Musik

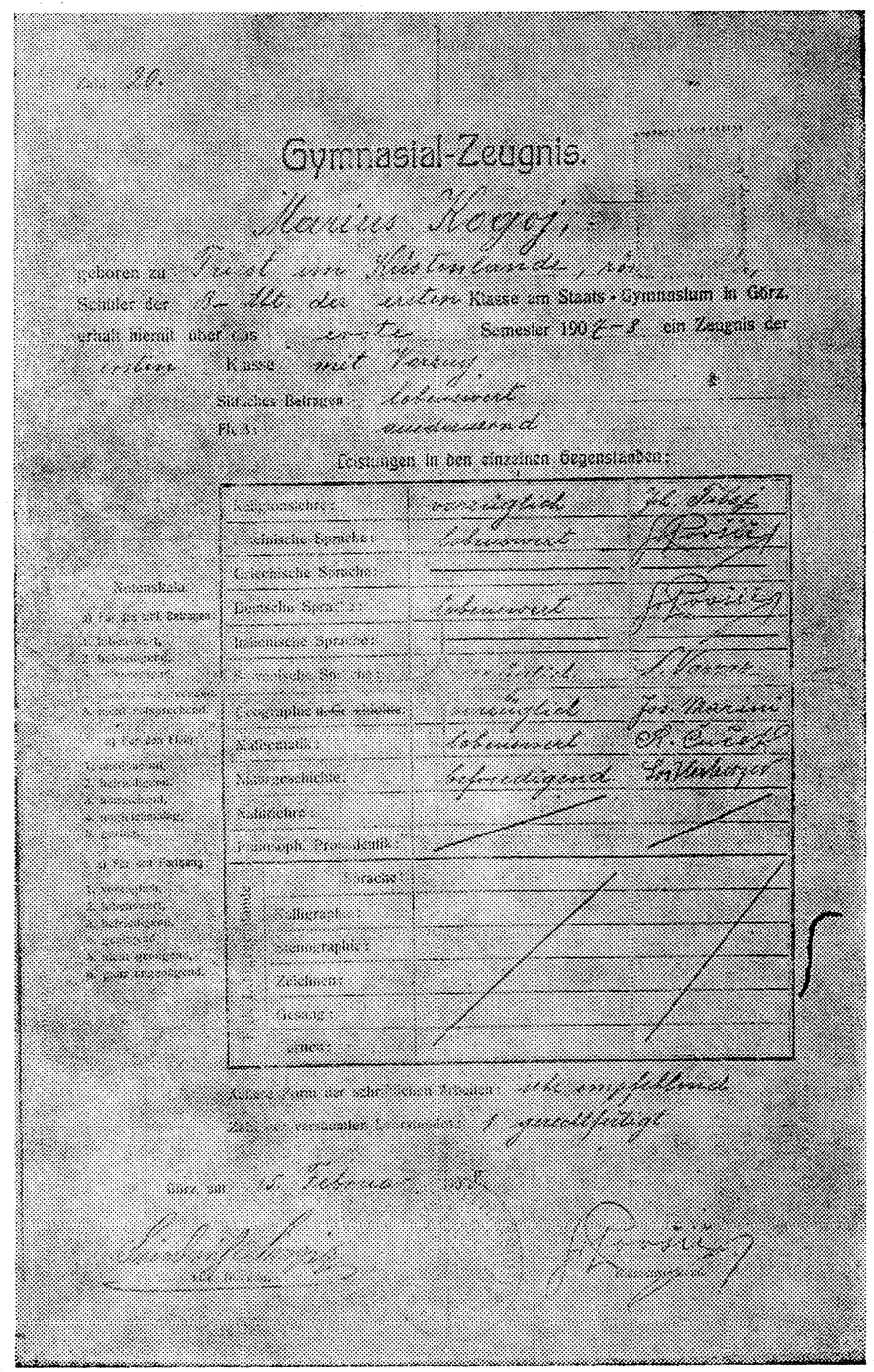


und darstellende Kunst na Dunaju. ${ }^{4}$ Tako je iz prvega ohranjenega, polletnega spričevala za prvi razred goriške gimnazije, izdanega 15. februarja 1908, razvidno, da je Kogoj začel obiskovati prvi razred gimnazije jeseni 1907. (gl. faksimile št. 1). Učenje mu je tu teklo kontinuirano, o čemer

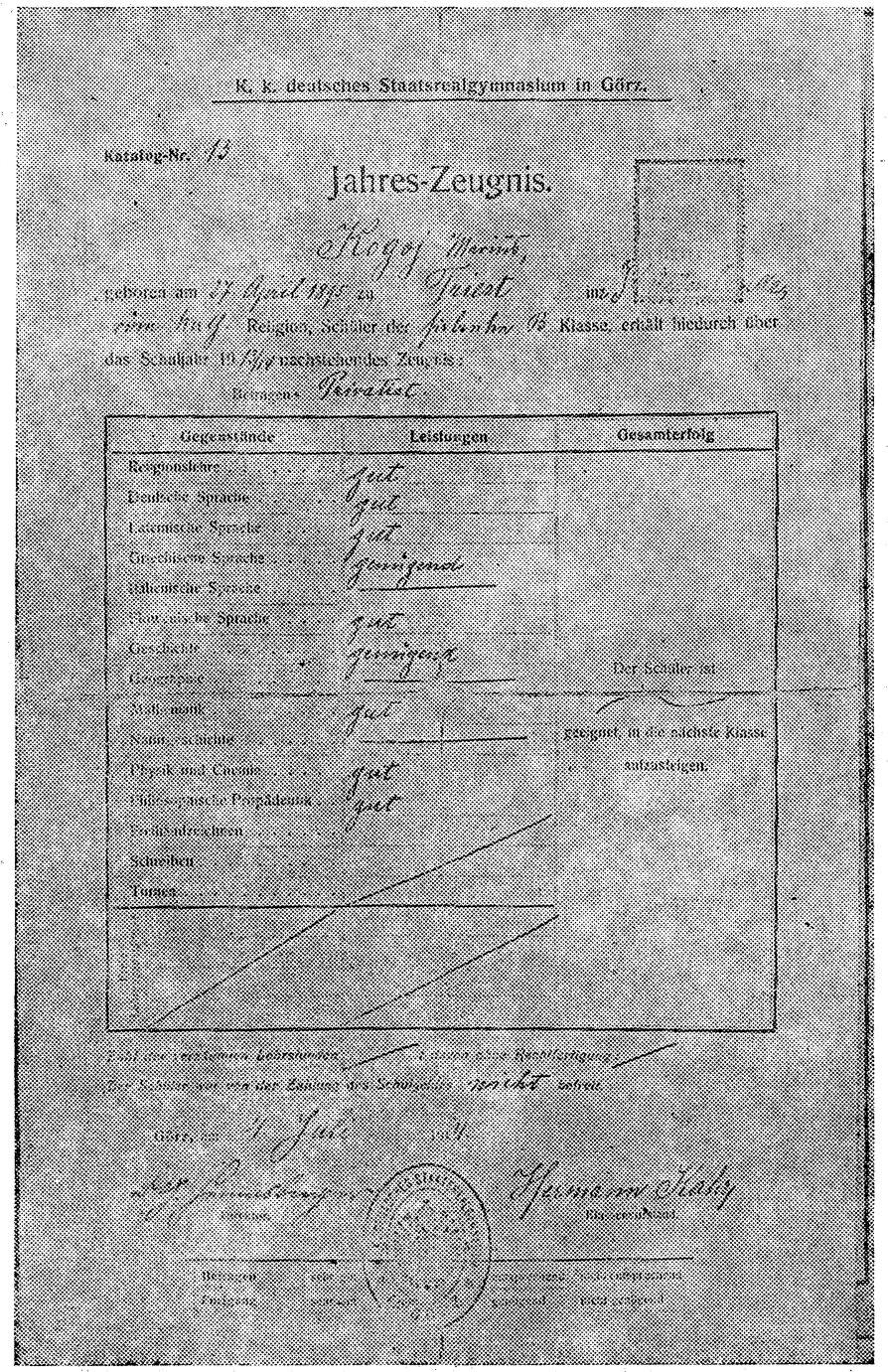

pričajo še ohranjeno letno spričevalo za četrti razred $\mathrm{z}$ dne 6. julija 1911, polletno spričevalo za peti razred z dne 10. februarja 1912 in letno spri-

4 Vsa ohranjena spričevala so v skladateljevi zapuščini, ki jo hrani sin Marij Kogoj. 
čevalo za sedmi razred z dne 4. julija 1914, ki ga je Kogoj opravil že kot privatist (gl. faksimile št. 2). ${ }^{5} \mathrm{~S}$ tem je gimnazijo predčasno in brez mature končal; namesto $\mathrm{v}$ njen zadnji letnik se je vpisal na dunajsko akademijo za glasbo, kar dokazuje spričevalo za prvi letnik $v$ šolskem letu

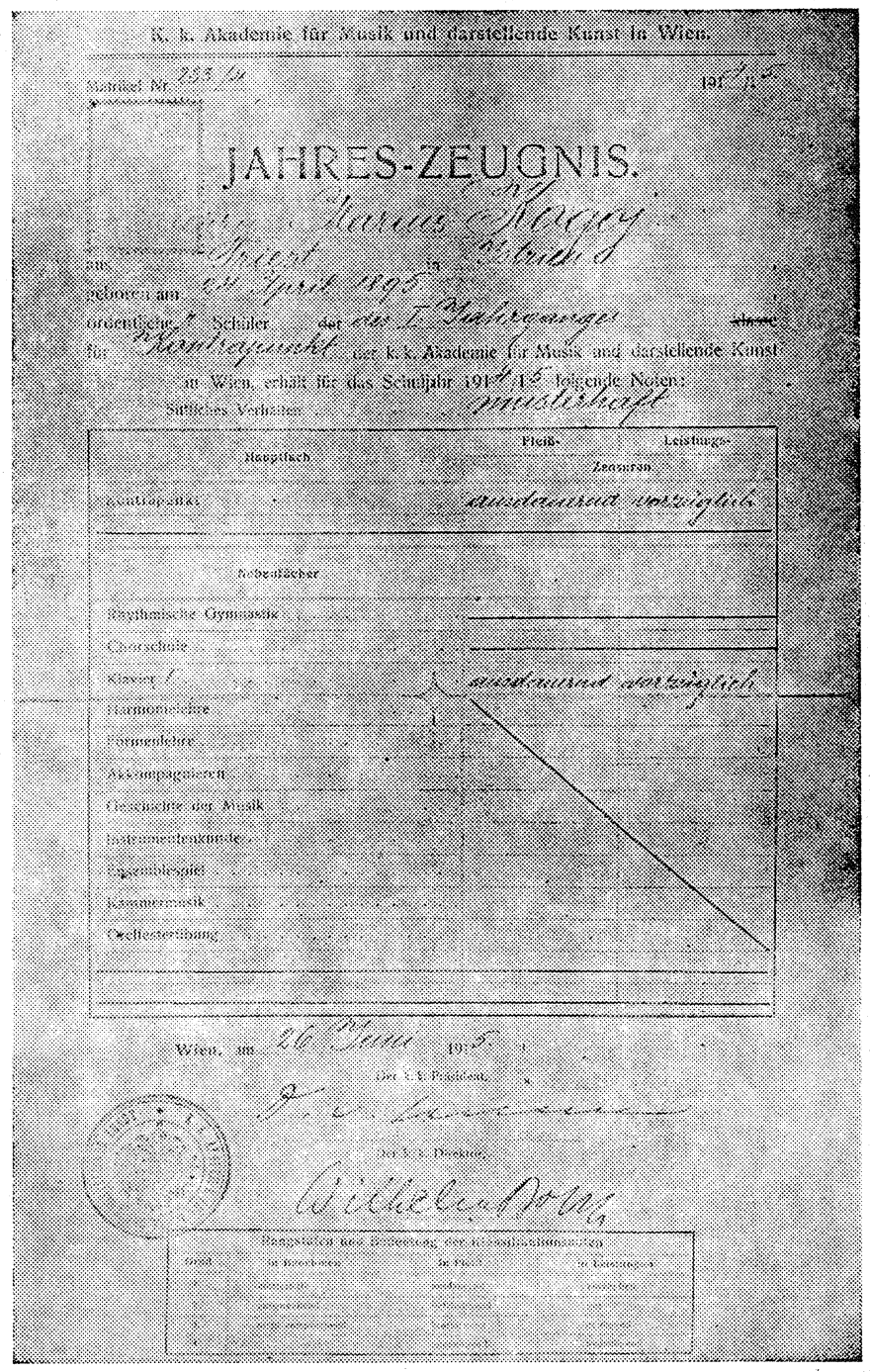

${ }_{5}^{5}$ Prim. tudi Jahresbericht des k. k. Staatsgymnasium in Görz za leta 1907-08 do 1912-13, kjer je skladatelj zabeležen $\mathrm{v}$ vseh šestih razredih B oddelka (s slovenščino), $\mathrm{v}$ prvih petih letih kot Kogoj Marius aus Görz in $\mathrm{v}$ šestem kot Ko. goj Marij. 
1914-15 z dne 26. junija 1915 (gl. faksimile št. 3) in še naslednje, zadnje spričevalo za letnik 1915-16 z dne 30. junija 1916.

Tako ni dvoma, da je moral skladatelj pri rojstni letnici 1892 začeti obiskovati gimnazijo v Gorici s 15 leti (dopolnjenimi 20. septembra) in je dovršil sedmi razred $z$ dopolnjenim 21 . letom, medtem ko bi jo pri stari rojstni letnici 1895 začel obiskovati s dvanajstimi leti, sedmi razred pa končal z 19 leti. Na akademijo bi se moral vpisati po prvi varianti z 23 leti, po drugi pa z 19 leti. Iz te primerjave torej vidimo, da gre zaradi Kogojeve nadpovprečne visoke starosti $\mathrm{v}$ gimnaziji in visoki šoli očitno prednost rojstni letnici 1895, pri kateri bi že tako lahko govorili o letu ali dveh višjih starosti za šolo od normalne. ${ }^{6}$

Ker je bila obveznost za osnovno šolo z dopolnjenim 6. letom starosti do 1 . septembra in so jo tisti, ki so se nameravali vpisati $\mathrm{v}$ gimnazijo, obiskovali 4 leta ali še bolj običajno 5 let, bi imeli ob vpisu $\mathrm{v}$ gimnazijo $\mathrm{v}$ najboljšem primeru 10 ali 11 let, ali $\mathrm{v}$ še dopustnih okvirih 12 let po dokončanih 6 razredih osnovne šole. ${ }^{7}$ Pri posebno nadarjenih, ki so jih izjemoma vpisali s 5 . letom, bi bila teoretična starost ob vpisu $\mathrm{v}$ gimnazijo celo 9 let. Seveda pa lahko v sicer rednem poteku tudi več kot 10 ali 11 let, če so se otroci zaradi olajševalnih okoliščin vpisali pozneje v osnovno šolo, ${ }^{8}$ ali če so jo obiskovali dalj časa ali v celoti, saj je bila za Primorsko in Dalmacijo obvezna osnovna šola 6 letna, tj. do dopolnjene starosti 12 let, sledila pa sta ji še dva ponavljalna razreda do dopolnjene starosti 14 let.' Poleg sprejemnega izpita je bil pogoj za vpis na gimnaziji starost nad 10 let, ki pa praktično ni bila omejena navzgor. ${ }^{10}$

Ce hočemo torej primerjati od gimnazijskih in visokošolskih zanesljivejše podatke o Kogojevi starosti $v$ šoli, moramo pogledati, kdaj je obiskoval osnovno šolo in še posebej, kdaj so ga vpisali $\mathrm{v}$ njen prvi razred.

6 Ce bi Kogoj pri rojstni letnici 1895 končal osemletno gimnazijo, bi imel 20 let in s to starostjo bi se tudi vpisal na akademijo za glasbo, torej oboje leto nad običajnim povprečjem. O dveh letih starosti nad povprečjem smemo govoriti zaradi takrat urejenega zgodnejšega vpisa $\mathrm{v}$ osnovno šolo.

${ }^{7}$ Ostanek F., Pregled razvoja osnovne šole na slovenskem ozemlju od 18691969, od str. 8, v: Ob stoletnici osemletne obvezne osnovne šole na Slovenskem 1869-1969, Ljubljana 1969; Sagadin J., Kvantitativna analiza razvoja osnovnega solstva na stajerskem, Kranjskem in Primorskem..., od str. 136, v: Osnovna sola na Slovenskem 1869-1969, Ljubljana 1970. Poleg tega sem dobil ustne podatke o pogojih za šolsko obveznost od Franceta Ostanka, upok. ravnatelja Slovenskega šolskega muzeja in upok. prof. Venceslava Čopiča.

* Gl. opombo 7. - Če je bil učenec eno uro hoda daleč od šole, so ga vpisali s 7. dopolnjenim letom do 1 . septembra, če je bil daleč $s$ hribov, s tako dopolnjenim 8. letom.

${ }^{9}$ Gl. opombo 7. - Vendar so osnovno šolo v celoti, torej poleg šestletne še dva ponavljalna razreda, $\mathrm{v}$ katerih je bi pouk ponavadi omejen na en ali dva dni tedensko in na jesenske in zimske mesece do spomladanskih poljskih del, obiskovali načeloma tisti, ki se niso imeli namena šolati $\mathrm{v}$ gimnaziji.

${ }^{10} \mathrm{Gl}$. opombo 7. - Zakon so smeli prilagoditi lokalnim potrebam, in ker je bil možen tudi vpis privatistov, so lahko imeli maturanti tudi precej čez 20 let. 
Dokumentacija o Kogojevem šolanju v Kanalu ni ohranjena, ker je bil celotni arhiv kanalske šole med prvo svetovno vojno uničen, ${ }^{11}$ prav tako ni ustreznih podatkov ali spričeval v skladateljevi zapuščini. Zato so bile ob tem in še nekaterih drugih vprašanjih potrebne poizvedbe, ${ }^{12} \mathrm{ki}$ nam $\mathrm{z}$ dobljenimi podatki dopuščajo nadaljnje sklepe. $\mathrm{V}$ Kanalu je bilo mogoče ugotoviti tri skladateljeve še živeče sošolce;13 zanje vemo, da so se bodisi vpisali $\mathrm{s}$ Kogojem $\mathrm{v}$ prvi razred jeseni leta 1900 , ali pa so se $\mathrm{mu}$ pridružili $\mathrm{z}$ ustrezno starostjo pozneje. ${ }^{14}$ Razhajajo se te osebe le $\mathrm{v}$ oceni skladateljeve starosti: Kogojeva sošolka Ema Zega meni, da je bil skladatelj nekoliko starejši od nje in torej rojen $1.1892,15$ medtem ko trdi sošolec Ivan Medvešček nedvoumno, "da je bil Kogoj Julij rojen leta 1895, kot že pokojni Mïjutin Garlatti, da pa sta prišla oba $\mathrm{s}$ petim letom v šolo, ker sta bila oba bistra in sta stanovala nasproti šole«. ${ }^{16}$

Vemo tudi, da je bila kanalska osnovna šola trirazrednica. ${ }^{17}$ Učiteljici sta sprejeli vsaka svoje učence $\mathrm{v}$ prvem razredu in jih vodili do četrtega. Imeli sta torej čiste razrede, po potrebi enega dopoldne in enega popoldne, ${ }^{18}$ zato ni moglo priti do pomote, da bi imel Kogoj za sošolce učence

${ }^{11}$ Gl. Slovenski šolski muzej, Ljubljana, mapa Kanal.

$12 \mathrm{~V}$ letih $1977-78 \mathrm{je} \mathrm{v}$ ta namen nastala $\mathrm{z}$ raznimi naslovniki korespondenca prek trideset dopisov ( $\mathrm{v}$ nadaljevanju Korespondenca); hrani jo glasbena zbirka Narodne in univerzitetne knjižnice.

${ }^{13}$ To delo je ljubeznivo in natančno opravila učiteljica Jožica Valentinčič iz Kanala. Gl. Korespondenco, dopise št. 8, 26 in 29.

${ }^{14} \mathrm{Gl}$. dopise J. Valentinčič, $i b$. - Kogojeva sošolka štefanija Berlot je bila rojena 29. XII. 1893 in je torej normalno začela obiskovati osnovno šolo jeseni 1900, z dopolnjenimi 6 leti do 1. septembra. - Upok. učiteljica Ema Gorjup, por. Zega se je rodila 10. IV. 1893 na Kanalskem Vrhu. Po razgovoru z njo piše Valentinčičeva, da je bila tu potovalna šola in da uso vpisovali v prvi razred vsako drugo leto. Tov. Zega pravi da so jo vpisali $\mathrm{v}$ šolo $\mathrm{s}$ sedmim letom. Po dveh letih šolanja na Vrhu je prišla v 3. razred $v$ Kanal v čisti razred učiteljice Karoline Leban. Tu je bil tudi Kogoj Julij, ki ga je uč. Lebanova spremljala še od prvega razreda - pa do četrtega." Zegova se spominja Kogoja kot sošolca iz tretjega in četrtega razreda, tj. iz šolskih let 1902-03 in 1903-04, pozneje pa ne več, čeprav je bila pred odhodom na goriške šole jeseni 1906 še dve leti na kanalski osnovni šoli. V pismih Valentinčičeve, dop. št. 26 in 29, se izjave Kogojeve sošolke E. Zegove $v$ dvoinpolmesečnem razponu ujemajo, potrjuje pa jih še zgodnejša izjava Zegove župniku Srečku Šuligoju iz Kanala, da "ga je imela [tj. Kogoja] za sošolca leta $1904 \mathrm{v}$ IV. razredu osnovne šole v Kanalü (Korespondenca, dop. št. 21). - Kogojev sošolec Ivan Medvešček iz Krstenic je bil rojen 5. VIII. 1894. Valentinčičevi, ki je tudi njega obiskala, je zatrjeval, «da je bil Kogojev sošolec 5 let, od leta 1900 do leta 1905«. Se pravi, da je tud on, kot Berlotova, začel obiskovati osnovno šolo normalno z dopolnjenimi šestimi leti 1. 1900. - Vidimo torej, da se letnica 1900 kot začetek šolanja ujema pri vseh treh. Zegova in Medvešček pa sta jo še podkrepila $\mathrm{z}$ izjavo, da sta bila in kdaj sta bila Kogojeva sošolca.

${ }_{15}$ Korespondenca, dop. J. Valentinčič št. 8 in dop. Sr. Šuligoja št. 21.

16 Korespondenca, dop. J. Valentinčič št. 29.

${ }_{17} \mathrm{Gl}$. Ročni zapisnik z imenikom ljudskih šol in učiteljskega osebja na Kranjskem, Južnem štajerskem in Primorskem, X/1903-04, ki ga je sestavil Stefan Primožič in Ročni kažipot po Goriškem, Trstu in Istri za leto 1902. Iz obeh virov razberemo, da so $\mathrm{v}$ kanalski trirazredni osnovni šoli učili nadučitelj Alojzij V(e)rč in učiteljici Karolina Leban ter Eliza Manzoni.

${ }_{18}$ Podatke navaja J. Valentinčič, dop. št. 29. 
iz sosednjih razredov, ki bi imeli skupaj pouk. V navedbah obeh sošolcev pa preseneča trditev Zegove, da se Kogoja več ne spominja iz 1. 1904-05 in $1905-06^{19}$ ali celo, da naj bi odšel $\mathrm{v}$ tem času za dve leti v pripravnico $\mathrm{v}$ Gorico in potem $v$ tamkajšnjo gimnazijo, ${ }^{20}$ kot tudi Medveščka, da je Kogoj odšel v Gorico po petem razredu osnovne šole. ${ }^{21} \mathrm{Da}$ bi bil skladatelj $\mathrm{v}$ resnici dve ali tri leta pred začetkom šolanja na goriški gimnaziji 1. 1907, v Gorici, nimamo nobenih drugih podatkov; vsekakor bi bilo to le malo verjetno. Vemo nasprotno, da se je pripravljal za sprejemni izpit na goriško gmnazijo v Kanalu, za kar je posebno skrbela Kogojeva učiteljica Karolina Leban, in da ga je Mihael Zega pred poletjem 1907 odpeljal iz Kanala na sprejemni izpit $v$ Gorico. ${ }^{22}$ Lebanova tudi poroča, da ga je $\mathrm{v}$ času teh priprav, torej nekako $\mathrm{v}$ šolskem letu 1906-07 obiskala v Kanalu njegova mati, ki da se je izdajala za teto in bi naj naredila na dečka velik vtis. ${ }^{23}$

Po vsem tem sklepamo, da so Marija Kogoja vpisali na osnovno šolo v Kanalu jeseni 1. 1900, da ga je tu učila štiri leta učiteljica Karolina Leban, naslednji dve leti pa verjetno nadučitelj Alojzij Verč. Zakaj ni že prej odšel v gimnazijo v Gorico, ne vemo. Vsekakor se je za odličnjaka, ki je bil sošolcem za vzgled, toda siroto brez denarja, zavzela Karolina Leban in najbrž odločilno pripomogla, da se je lahko vpisal na goriško gimnazijo. ${ }^{24} \mathrm{Ob}$ pomanjkanju drugih virov iz tega časa smemo vsaj domnevati, da se je Lebanova šele takrat, to je po Kogojevih končanih šestih razredih osnovne šole in ne morda že po končanem četrtem ali petem razredu, odločila, da dečka pripravi in pošlje na študij v gimnazijo. Tako je torej Kogoj v skladu s šolsko obveznostjo najbrž obiskoval v šolskem letu 1906-07 sedmi, to je ponavljalni razred kanalske osnovne šole, ${ }^{25}$ vse-

${ }_{19} \mathrm{~J}$. Valentinčič, dop. št. 26 in 29. - Zegova je odšla na solanje v Gorico jeseni 1906, tako kot Medvešček.

${ }^{20} \mathrm{Sr}$. Šuligoj, dop. št. 21. - Suligoj tu tudi piše, da je bil med prvo svetovno vojno uničen precejšen del župnijskega arhiva $\mathrm{v}$ Kanalu in da ni tu nikakršnih pođatkov o Kogoju.

${ }^{21}$ J. Valentinčič, dop. št. 29.

${ }^{22}$ Leban K., V Kanal ob Soči so pripeljali tri sirote. ib. - Lebanova navaja, da je dečka poučevala nemščino, kateheta Pečenka pa je naprosila, da ga je pripravljal $\mathrm{v}$ fiziki in matematiki. Iz besedila je razvidno, da so bile priprave za sprejemni izpit $\mathrm{v}$ Kanalu.

${ }^{23}$ Leban K., ib. Gl. tudi Jež J., op. cit.

${ }^{24}$ Karolina L., ib. - Kogojeva učiteljica tu piše, da je sklenila otroku "pripraviti boljšo bodočnostı, s čimer je mislila na nadaljevanje šolanja po osnovni šoli in vsaj na duhovniški poklic. Poleg pomoči pri pripravah za sprejemni izpit je dečku zagotovila podporo kanalskega župana in ga osebno priporočila $v$ Malem semenišču v Gorici, kjer je potem v resnici bival brezplačno, pri ravnatelju gimnazije pa izprosila knjige in druge potrebščine in mu bila najbrž tudi sicer $\mathrm{v}$ oporo in pomoč.

${ }^{25} \mathrm{~V}$ 7. in 8. razredu kanalske šole je bil pouk dvakrat tedensko od $10^{\mathrm{h}}-13^{\mathrm{h}}$. Gl. J. Valentinčič, dop. št. 29. 
kakor pa se je $\mathrm{v}$ tem šolskem letu pripravljal za sprejemni izpit na gimnazijo, ${ }^{26} \mathrm{ki}$ ga je ob koncu tega šolskega leta opravil $\mathrm{z}$ odlično oceno. ${ }^{27}$

Odtod torej sklepamo, da je moral skladateij začeti hoditi $\mathrm{v}$ osnovno šolo pri rojstni letnici 1892 formalno s sedmimi leti, ${ }^{28}$ praktično pa jih lahko štejemo osem, pri rojstni letnici 1895 pa s petimi leti. Zlasti ker je bil pri krušnih starših in še tudi ker je moral biti kot odličnjak očitno dovolj bister, stanoval pa je v neposredni bližini šole, bi bila starost 5 let, 4 mesece in 3 dni do 1 . septembra za vpis še prav tako dopustna ali zaradi opisanih okoliščin celo precej verjetna. Nasprotno pa ne poznamo nobenih posebnih okoliščin, ki bi opravičevale ob vpisu izjemno visoko dečkovo starost osem let. Prej kot rojstno leto 1892 bi prišla $v$ poštev rojstna letnica 1894, ali še nekaj mesecev pred njo, saj bi imel takrat deček ob vpisu najmanj problematično starost šest let. Kar zadeva dečkovo starost po izgledu, pa so si po izjavah Kogojevih sošolcev Zegove in Medveščka mnenja različna, medtem ko Kogojeva učiteljica Lebanova tega vprašanja ne omenja. Kaže le, da je bila $v$ šoli med Kogojevo najmlajšo sestro Ano, rojeno 12. I. 1897, ki jo je Lebanova tudi učila, in Marijem, dvoletna razlika. ${ }^{29}$ Tako smemo sklepati, da je začela hoditi Ana Kogoj $\mathrm{v}$ šolo jeseni 1902 pri starosti 5 let, 7 mesecev in $19 \mathrm{dni}$, torej podobno, kot bi to lahko veljalo dve leti prej za Marija pri rojstnem letu 1895 .

Iz tega obdobja osnovnošolskega šolanja pomemben in nenavaden je še dogodek $\mathrm{s}$ krstnim listom in zamenjavo imena. Ko je učiteljica Lebanova pripravljala Kogoja za sprejemni izpit na goriško gimnazijo, so 1. 1906 pisali v Trstu za njegov krstni list, ki so ga rabili za prijavo $\mathrm{k}$ izpitu. $\mathrm{K}$ temu je treba dodati, da so dotlej dečka klicali vedno Julij. ${ }^{3}$ Zato je bil odgovor iz Trsta, da je Julij Kogoj mrtev in da živi Marij, nadvse presenetljiv. Dokaj nenavadno je bilo tudi, da so se skrbniki takoj odločiti preimenovati dečka iz Julija $\mathrm{v}$ Marija, ${ }^{31}$ torej $\mathrm{v}$ ime, ki mu je ostalo ves čas pozneje.

Sam krstni list ${ }^{32}$ (gl. faksimile št. 4) z dne 12. novembra 1906 so v celoti pravilno izstavili na ime Marij Kogoj, z rojstno letnico 27. IV. 1895. Toda kar je vsaj toliko nenavadno in presenetljivo, je dejstvo, da so $\mathrm{v}$

\footnotetext{
26 G1. opombo 22.

${ }^{27}$ Leban $\mathrm{K}$., ib.

${ }^{28}$ Točneje $\mathrm{s} 7$ leti, 11 meseci in 10 dnevi; osem let bi napolnil le 20 dni po 1. septembru 1900.

${ }_{29}$ Lebanova, ib., navaja, da je najprej začela učiti Kogojevo sestro Ano, "dve leti pozneje pa je prišel k meni v šolo tudi dečeku. Ker se je Ana robila 1897, gre za očitno pomoto: Ana je morala priti dve leti za bratom k Lebanovi, upoštevajoč pri tem Marijevo rojstno letnico 1895 (dveletni razmik bi se ujemal z verjetno prakso, da sta učiteljici izmenoma prevzemali prvi razred vsako drugo leto),

${ }_{30}$ Leban K., ib. Prim. tudi Jež J., op. cit. in dop. J. Valentinčič št: 8, 26 in 29:

${ }^{31} \mathrm{O}$ tem piše Lebanova, ib.: "Za pripravo $\mathrm{k}$ izpitu in $\mathrm{za}$ sprejem $\mathrm{v}$ gimnazijo je bil potreben tudi krstni list. Po listino smo pisali $\mathrm{v}$ Trst, toda odgovor se je glasil: 'Julij Kogoj je že davno mrtev, živi le še Marij.' In poslej smo tudi mi preimenovali dečka $\mathrm{v}$ Marija.॥

32. V skladateljevi zapuščini, ib.
} 
rojstnih in mrliški knjigi $\mathrm{v}$ župnijskem arhivu sv. Antona Padovanskega v Trstu pravilno vodili za živega Julija, za mrtvega pa Marija, kar je nedvoumno dognal P. Merkù. ${ }^{33}$ Prav tako preseneča, kot je bilo že omenjeno, da skrbniki dotlej imenovanega Julija niso skušali zadeve popraviti ali vsaj preveriti in ugotoviti resnico, ampak so se $z$ odgovorom spri-

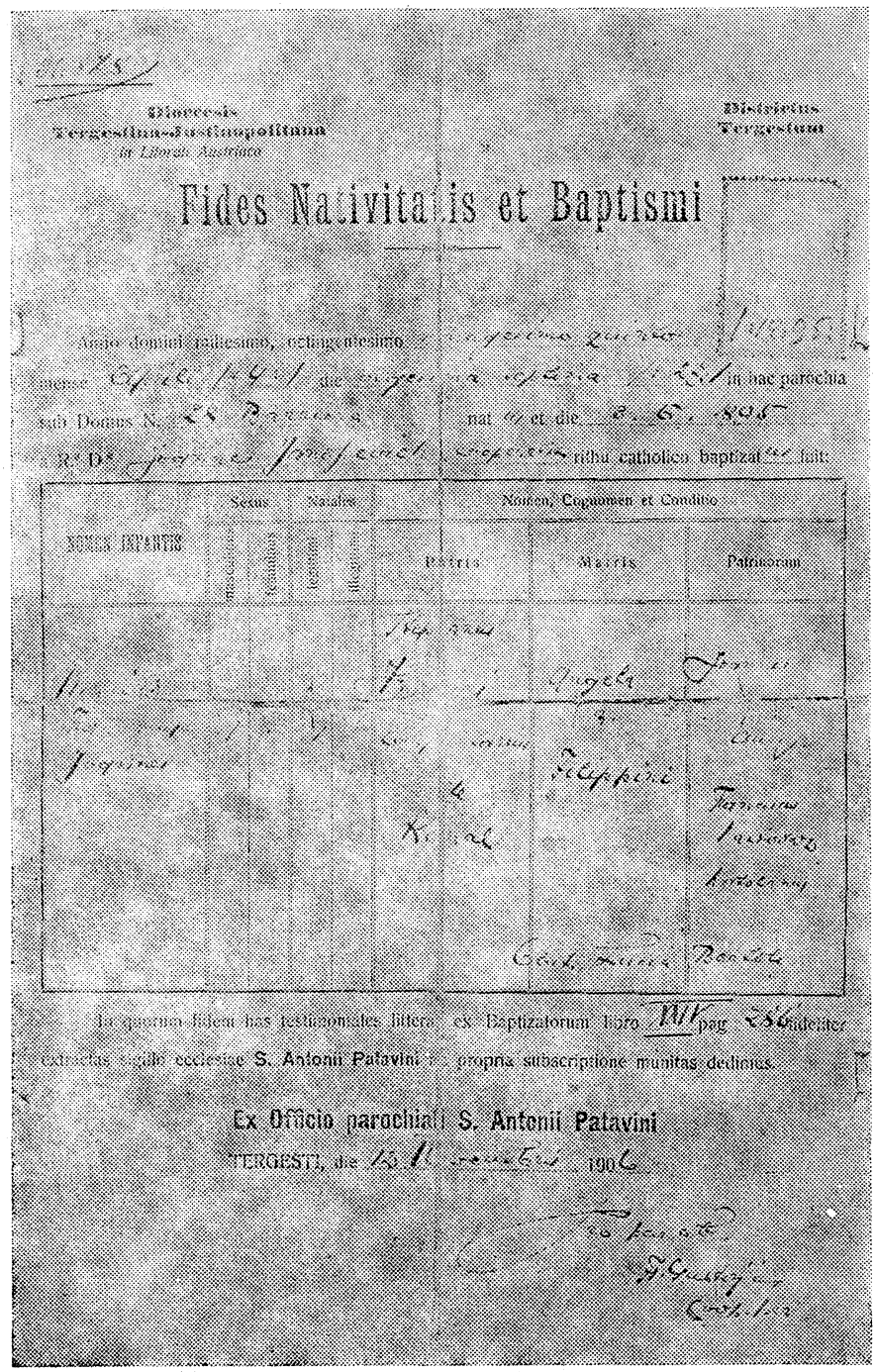

${ }^{33}$ Merkù P., ib. Tudi izpisna številka knjige (XXIV) in strani (286) v rojstn1 knjigi se ujemata $\mathrm{z}$ navedbo na krstnem listu. 
jaznili in so dečka, očitno v novembru 1906, preimenovali po umrlem bratu Mariju. ${ }^{34}$ Pri tem tudi ne kaže, da bi se jim zdel otrok prestar za rojstno leto 1895 , saj bi bilo mogoče to že opaziti.

Kakor je zadeva $\mathrm{v}$ celoti izjemna in presenetljiva, je na podlagi doseggljivega gradiva ni mogoče dokumentirano pojasniti. ${ }^{35}$ Slej ko prej ostaja tu sporno vprašanje, zakaj so menili v župnijskem uradu pri sv. Antonu v Trstu, da je Julij mrtev in da živi Marij, in to kijub pravilno vodenim rojstnim in mrliškim knjigam, po katerih je bil Julij živ, Marij pa mrtev. Ugibamo lahko, ali je bila to le napaka tehnične narave, če je pri tako odločilnih zadevah sploh možna, ${ }^{36}$ ali je bila celo namerna in je bilo posredi še kaj drugega, morebiti kakšni posebni interesi ipd.

Ko moramo pustiti to vprašanje zaenkrat odprto, nam bi lahko dosedanje posredno sklepanje, ki bolj kaže na skladateljevo rojstno leto 1895 , še bolje osvetlilo vprašanje prihoda Kogojevih otrok iz Trsta v Kanal. O tem imamo nekaj podatkov. Kogojeva učiteljica Lebanova navaja kot čas prihoda treh sirot prva leta našega stoletja; 37 podatek, ki glede na dognano letnico začetka Kogojevega šolanja $v$ Kanalu 1. 1900 ni točen. Kogojev goriški rojak Ludvik Zorzut piše, da je otroke «pripeljal tedanji kanalski občinski tajnik Anton Bajt,« ko je imel naš skladatelj pet let, torej 1. 1900.38 Vemo tudi, da je starejši brat Angel Kogoj pobegnil

${ }^{34}$ Merkù P., ib., trdi nekajkrat, da so Julija preimenovali v Marija takoj po Marijevi smrti 1. 1896, torej 10 let prej. To navedbo, ki ni tudi z nicemer utemeljena, je treba torej popraviti.

${ }^{35}$ Kogojevi skrbniki so verjetno dobili neke podatke o skladateljevem rojstvu, ko je prišel ta kot sirota iz Trsta $\mathrm{v}$ Kanal, vendar ne vemo katere (prim. tudi op. 20). Najbrž so ti skrbniki morali poznati neko rojstno letnico, s katero so računali ob raznih priložnostih (vpis v šolo, cerkvene obveze, rojstni dnevi ipd.), mogoče z letom 1895; toda če bi se nanjo celo sklicevali pri prošnji za krstni list, potem še vedno preseneča odgovor iz Trsta, da je Julij mrtev (če ta odgovor Lebanova točno povzema). Se pravi, da je sporno tudi to, da bi se skrbniki hoteli pri izdaji krstnega lista prilagoditi dečkovi rojstni letnici 1895, tudi za ceno spremembe imena.

${ }^{36}$ Pri zbiranju teh in drugih podatkov mi je zelo požrtvovalno in samoiniciativno pomagal Hubert Močnik iz italijanske Gorice, upokojeni prosvetni delavec $\mathrm{z}$ odgovornimi nalogami in publicist, Kogojev sodobnik (r. 1893). Tako je med drugim iskal $v$ goriški državni knjižnici in na liceju Dante Alighieri podatke o Kogoju, zlasti če bi se nanašali na čas šolanja $v$ osnovni šoli, a ni našel ničesar (prim. Korespondenco, dop. št. 2). Za preverjanje podatkov ob izstavitvi krstnega lista 1. 1906 je naprosil dr. Jožeta Prešerna, kaplana pri sv. Antonu Padovskem v Trstu, kjer je bil Kogojev krstni list sestavljen (gl. Korespondenco, dop. H. Močnika št. $12,15,16$ in 17 , s prilogama odgovorov Jožeta Prešerna z dne 7. in 24. maja 1977, ter dop. J. Prešerna št. 25). Prešeren je lahko le potrdil podatke, ki jih je že dognal P. Merkù, ni pa mogel pojasniti glede na tehniko vodenja rojstnih in mrliških knjig (mogoče kakšne pomožne knjige $z$ napačnimi podatki), kako bi vendarle lahko prišlo do pomote pri izstavitvi krstnega lista.

${ }^{37}$ Leban K., ib.

${ }^{38}$ Zorzut L., Kogojeva prva srečanja z glasbo, v: Ob stoletnici kanalske citalnice in ob odkritju spomenika Mariju Kogoju, Kanal 1967, 39. Podatke je avtor zbral po pričevanju učiteljice Lebanove in najbrž ljudi iz Kanala, pri čemer je računal z rojstnim letom 1895. 
nazaj v Trst, ker so $\mathrm{z}$ njim slabo ravnali, mlajša dva, Anico in našega skladatelja Julija pa so dali $\mathrm{v}$ rejo ženi kanalskega občinskega obhodnika Ani Perkonovi, p.d. Srovinčevi ali nuni Srovinčevi, rojeni Juvančič ali Ivančič, p.d. Kokčevi iz Deskel. ${ }^{39}$ Vdova Perkonova je za njiju dobro skrbela, da sta jo imela za pravo mater. ${ }^{40}$ Naposled je tu še pričevanje Kogojeve sestre Ane. ${ }^{41}$ Ta se po pripovedovanju sorodnikov spominja odhoda matere, ki je zapustila otroke kmalu po smrti očeta štefana Kogoja 8. I. 1898, ko sta bila z Marijem v bolnišnici. ${ }^{42} \mathrm{Ne}$ ve točno, kdaj so prišli vsi trije otroci v Kanal, ali 1898 ali 1899; spominja pa se, da takrat še ni hodila. ${ }^{43}$

Sodeč po teh navedbah so za nas najbolj sprejemljivi in smiselni podatki Kogojeve sestre Ane. Ker ta trdi, da jih je mati zapustila kmalu po očetovi smrti, je tudi malo verjetno, da bi bili po tem dalj časa ostali v Trstu v breme tržaške občine. ${ }^{44}$ Glede na to bi bilo verjetno in dopustno sklepanje, da so prišli otroci v Kanal že prav kmalu po očetovi smrti, ali še nekje do spomladi 1. 1898, ko Ana Kogoj mogoče tudi še ni shodila, manj verjetno, vsekakor najpozneje pa 1. 1899.

${ }^{39}$ G1. Korespondenco, dop. J. Valentinčič št. 8 in 26; dop. Sr. Suligoja št. 21; Leban K., ib,: Zorzut L., ib.

${ }^{40}$ Korespondenca, dop. J. Valentinčič št. 8.

${ }^{41}$ Gl. Pismeni odgovori Kogojeve sestre Ane skladatelju Jakobu Ježu (napisani do 1. 1958), v Kogojevi zapuščini, ib. Prim. tudi Jež J., op. cit., ki se je naslanjal na tu navedene podatke Kogojeve sestre Ane in učiteljioe Lebanove.

42 Pismeni odgovori Kogojeve sestre Ane, ib. Tu beremo, da je mati "dala bratu Angelu 2 kroni, brat Marij in jaz sva bila $v$ bolnici, in je odšla $v$ Italijo. To se je zgodilo nedolgo po očetovi smrti, mislim.u Po tej navedbi sta bila torej Ana in Marij 1. $1898 \mathrm{v}$ bolnišnici, najbrž tržaški, medtem ko je iz Merkùjeve obravnave, ib., razvidno, da je bil Marij (seveda $z$ imenom Julij) v goriški bolnišnici že 1. 1895; kaže torej, da je bil deček dvakrat bolan, najbrž težje.

${ }^{43}$ Pismeni odgovori Kogojeve sestre Ane, ib. Že pokojna Ana Kogoj, por. Bratos iz Trsta, piše: "Marij je pravil, da se spominja [očetovega] pogreba, jaz sem pa prišla v Kanal, ko nisem še hodila, oče je pa umrl, ko jaz še nisem imela leto." In nekoliko naprej: "Tudi kdaj smo prišli v Kanal [ne vem] nič točnega, ali 1888 ali 1889 [očitno napaka, prav: 1898 ali 1899]." Zvemo še, da bi morali po takratnem zakonu po 24 letih še 10 let stalno bivati $v$ Trstu, da bi bili pristojni tržaški občini in bi ta morala skrbeti za sirote. Zato pravi, smo ibili poslani kanalski občini, kjer je imel moj oče domovinsko pravico. Sorodnike smo sicer imeli, a uboge in ti se niso za nas nič brigali. Marij in jaz sva bila pri Ani Perkon; ta nas je vzgajala in bila res dobra mama.» - Med seboj nista povsem skladna le podatka A. Kogoj, ko pravi, da ob prihodu $\mathrm{v}$ Kanal še ni hodila, po drugi strani pa omenja letnici 1898 ali 1899. Domnevati smemo, da je $\mathrm{z}$ enim letom ali s poldrugim letom kljub verjetno slabi oskrbi in bolezni že shodila; vsekakor pa $\mathrm{v}$ letu 1899 , ko je imela 2 leti, zato je to leto kot čas odhoda iz Trsta že vprašljivo. - Podobno se po Kogojevem pripovedovanju spominja Josip Vidmar, Dva spomina (Cankar, Kogoj), Sodobnost XXIII/1975, 769: ». .. po njegovi [tj. očetovi] smrti je mati menda tri otroke zaklenila $v$ stanovanje in izginila... Otroke so rešili iz stanovanja, nato so jih kot zapuščene sirote poslali v očetov rojstni kraj, v Kanal ...."

${ }^{44}$ Jež J., op. cit., 2, piše, da sta bila Marij in Ana po materinem odhodu $\mathrm{v}$ zavetišču. Če je bilo tako, sta bila tam seveda le začasno in zato najbrž ne dolgo. 
Če pa so tri sirote $\mathrm{v}$ resnici prišle v Kanal vsaj do poletja 1898, ali še tudi v naslednjem letu, je treba pojasniti, zakaj niso Marija takoj vpisali $\mathrm{v}$ šolo. 1. septembra 1893 bi mu pri rojstni letnici 20. IX. 1892 manjkalo 20 dni do napolnjenih 6 let, naslednje leto prav toliko dni do napolnjenih 7 let. $\mathrm{V}$ okoliščinah, $\mathrm{v}$ katerih je živel kot sirota pri Perkonovih, vsekakor ne najdemo nobenega razloga, da ga ne bi takoj poslali $\mathrm{v}$ šlo in da bi moral čakati še dve ieti na vpis do svojega 8. leta (dopolnjenega 20. septembra). Ce je sklepanje točno, je možno le, da je bil mlajši letnik; glede na letnico vpisa $\mathrm{v}$ osnovno šolo 1.1900 . in starost 5 ali 6 let torej rojen $\mathrm{v}$ časovnem razponu priwižno od konca 1893 do približno 1. IX. 1895, pri čemer pa so glede na okoliščine poznejši datumi v tem razponu verjetnejši. Zanimivo je tudi, da Kogojeva sestra Ana in ravno tako učiteljica Lebanova nikoli ne omenjata, da bi bil po izgledu starejši za njima poznano rojstno letnico $1895^{45}$ - čeprav vemo tudi za drugačna mnenja;46 prva bi namesto manj kot dveletne razlike $\mathrm{z}$ bratom, $\mathrm{s}$ katero je računal, ${ }^{47}$ morala opaziti več kot štiriletno razliko pri rojstni letnici 1892 , in podobno Lebanova, ki je otroka učila.

Iz tega prikaza Kogojevega šolanja in iz drugih okoliščin, ki so nam zaenkrat poznane, torej ne moremo sklepati, da bi bil skladatelj Marij Kogoj rojen leta 1892. Dasiravno zaradi posrednega sklepanja na podlagi dostopnega gradiva te letnice ne moremo povsem izključiti, je mnogo verjetnejše, da se je rodil 1895. leta ali eno leto prej. Kot je $s$ tem močno sporen datum 20. IX. 1892, je po dokazih P. Merkùja nesprejemljiv tudi rojstni datum 27. IV. 1895 v osmem mesecu umrlega Marija; o kakršnih koli zamenjavah, namernih ali nenamernih, ki bi vendarle potrdile to letnico, lahko ob vsaj doslej poznanih okoliščinah le ugibamo, a je prav zato. tudi ne moremo povsem izključiti. Prav tako ostaja zadeva $\mathrm{z}$ napačno izstavitvijo krstnega lista in $\mathrm{z}$ zamenjavo imen $\mathrm{v}$ tem obsegu zaenkrat poznanih podatkov nezadostno pojasnjena in odprta. Vidimo torej, da je bilo v otroštvu in ob samem rojstvu Marija Kogoja mnogo nenavadnega in še do danes nepojasnjenega. Vprašanje je, ali bodo podatki, ki sem jih zbral zadnji dve, tri leta in ki kažejo na povsem drugačno skladateljevo genealogijo, pripomogli $\mathrm{k}$ razjasnitvi nekaterih doslej odprtih vprašanj

${ }^{45}$ Pismeni odgovori Kogojeve sestre Ane, ib. in Leban K., ib. Prim. tudi že c\%. trditev Kogojevega sošolca Medveščka, da je bil mlajši (Korespondenca, dop. J. Valentinčič št. 29).

${ }^{46} \mathrm{O}$ večji starosti od nje je govorila sošolka $\mathrm{E}$. Zega (Korespondenca, dop. Sr. Šuligoja št. 21) in J. Vidmar, ib., ki se mu je zdela Kogojeva rojstna letnica 1892 popolnoma verjetna: "... Marij naj bi bil po dokumentih moj vrstnik ali celo leto mlajši od mene [kot se vidi iz Vidmarjeve rojstne letnice 14 . X. 1895 in Marijeve 1895, je bil slednji pol leta starejši od Vidmarja], zdel pa se mi je zmeraj telesno in umsko znatno zrelejši.u Mogoče bi bilo seveda, da je Kogoj zaradi svoje južnjaške narave hitreje dozorel.

47 Pismeni odgovori Kogojeve sestre Ane, ib.: «Marij je rojen 1895, jaz 1897. Angel, najstarejši sin, [se je rodil] kakih 10 let prej [od Ane], a točno ne vem, umrl pa je 1956. leta." Ker je bil Angel Kogoj rojen 3. X. 1888, je razlika 9 let, se pravi, da se sestra njegove starosti dovolj spominja. 
in nelogičnosti, ali bodo vnesli vanje novo nejasnost. Vsekakor je prav, da jih tu navedem.

Gre za pričevanje Alojza Andolška, ki je Kogoja dovolj dobro poznal iz Gradeža pri Turjaku iz obdobja po prvi svetovni vojni. ${ }^{48}$ Andolšek se spominja,49 da mu je o rodu Marija Kogoja govoril njegov ded Jože Sevnik, ki je umrl nekako ob prvi balkanski vojni 1912. in sam Kogoj, ki mu je bila zadeva o rodu prav tako poznana; le ne ve, kje naj bi jo ta zvedel, mogoče od svojih rednikov ali iz nekih listin ali kako drugače. V svoji pripovedi je Andolšek segel do svojega pradeda Sevnika - njegovega imena se ne spominja, ki je živel na Gradežu št. 2 kot posestnik, gostilničar, trgovec in turjaški župan. $Z$ ženo p.d. Rojčevo iz Rožnika ${ }^{50}$ je imel dva sinova, Janeza in Andolškovega deda Jožeta. Janez Sevnik je dobil menda nekje v okolici nezakonsko hčerko Julijo Sevnik,51 ki je odraščala na Gradežu. Še pred avstrijsko zasedbo Bosne 1.1378 je odšel Janez v Združene države Amerike, v Minnesoto, kjer je bil eden od vodij neke tovarne in je dobro zaslužil. Svojo hčerko Julijo pa je poslal za okoli šest do osem let na študij v Trst, ker je bila, kot Sevniki na splošno, sposobna za uče-

48 A. Andolšek, rojen 27. III. 1903 na Gradežu št. 2, p. d. pri Zevniku; upokojenec mizarske in tesarske stroke, igral $\mathrm{v}$ godbah na pihala evfonij in bombardon (1. in 2. bas), $\mathrm{v}$ letih 1923-25 v Vojni muziki jugoslovanske mornarice, s katero je obšel precejšen del sveta. Njegova rojstna hiša na Gradežu 2 stoji čez cesto nasproti hiše Podlogarjevih (p. d. Koščičarjeve hiše), kamor se je priženil Marij Kogoj (poroka je bila 27. III. 1919). Tu se je spoznal s Kogojem, se z njim videval in bil $\mathrm{z}$ njim $\mathrm{v}$ dobrih odnosih. Kogoj je pogosto zahajal $\mathrm{v}$ Zevnikovo hišo, kjer se je počutil kot doma. Njuno znanstvo je prekinilo Kogojevo bivanje v Gorici od poletja 1922 za eno leto ali leto in pol (prim. Klemenčič I., Kompozicijski stavek $\mathrm{v}$ klavirskih skladbah Marija Kogoja, Ljubljana 1976, 108 in opomba 11) vse do vrnitve Andolška od vojakov 1925. leta. L. 1930 je odšel Andolšek začasno, od maja ali junija 1933 pa za stalno $\mathrm{v}$ Ljubljano in je le občasno prihajal v Gradež, kjer se je še videval s Kogojem.

${ }_{49} \mathrm{Z}$ A. Andolškom sem se pogovarjal 1. I. 1976, 21 I. 1977, 4. II. 1977 in 25. II. 1978, torej $\mathrm{v}$ daljšem časovnem razponu, $\mathrm{v}$ katerem je ohranil vedno isto bistvo pripovedi; le nekatere podrobnosti je povedal drugače in jih je na mojo pripombo popravil $\mathrm{v}$ sprejemljivo dokončno obliko. Zaradi nezanesljivosti spomina po tolikih letih je treba najbrž posamezne trditve jemati tudi kritično in $\mathrm{s}$ priđ̈ržki.

${ }_{50}$ Vas med Malimi in Velikimi Lipljeni, severovzhodno od Gradeža.

51 Andolšek sprva ni zanesljivo vedel, če ji je ime Julija, pozneje jo je stalno le tako imenoval in je mislil, da je to njeno pravo ime. Rojena naj bi bila Julija vsaj približno okoli 1. 1875. Jožetova hčerka Marija tj. Andolškova mati (por. z Jernejem Andolškom) je umrla 1918 za špansko boleznijo, stara 33 let. Rojena je bila torej 1885, Julija pa naj bi bila od nje starejša ok. 10 let. Andolšek je tudi povedal, da so vso obsežno dokumentacijo z Gradeža (knjige o župljanih ipd.) in iz sosednjega škocjana (na zemljevidu označen kot Staro Apno vas in fara) med drugo svetovno vojno $v$ bojih odnesli in uničili partizani. Tako ostajajo ti podatki nedokumentirani in časovno približno določeni.

52 Andolšek se ne spominja, ali se je vpisala $\mathrm{v}$ kakšno srednjo ali visoko šolo. Domnevamo lahko, da $\mathrm{v}$ srednjo šolo, morda $\mathrm{v}$ prvi razred med leti 1885-90. Pregled letnih šolskih poročil za Trst (rokopisna zbirka NUK hrani sedem naslovov) ni potrdil navzočnosti Julije Sevnik v Trstu. Več verjetnosti je, da bi se vpisala v žensko srednjo šolo, takrat Civico liceo Femminile di Trieste (za letna poročila za leta 1885-86 do 1898-99 sem poizvedoval v Trstu, zaenkrat brez odgovora). 
nje in umsko delo.52 V Trstu je dobila Julija Sevnik okoli $1.1895 \mathrm{z}$ nam nepoznanim Italijanom $\mathrm{v}$ zakonu ali še verjetneje zunaj njega sina. Ta otrok, ki mu Andolšek ne ve imena, je bil nam poznani skladatelj Marij Kogoj. Njegova mati Julija je kmalu po porodu umrla. Andolšek se spominja, da je bil z dedom Jožetom na njenem grobu v Trstu ok. 1. 1908-09, verjetno na mestnem pokopališču sv. Ane.53

Janez Sevnik je pošiljal hčerki Juliji denar v Trst, večjo vsoto pa je poslal ob rojstvu njenega sina in menda še pozneje. Otrok je bil $\mathrm{v}$ reji pri neki Italijanki. Po smrti Julije, ki zaradi tega denarja morda ni umrla naravne smrti, naj bi si otrokov denar prisvojila otrokova skrbnica, ki je kmalu zatem izginila neznano kam. ${ }^{44}$ Nadaljnja usoda tega Julijinega otroka Andolšku ni bila poznana; 55 kdo je bil ta otrok, je Andolšku kmalu po prvi vojni povedal Marij Kogoj.

Po Andolškovi pripovedi je torej Marij Kogoj sam trdil, da je bila Julija Sevnik njegova mati56 in je še posebno odločno zanikal, da bi bil njegov oče kolar štefan Kogoj: „kakšen kolar, kakšen bobnar [tj. kolar].॥ Andolšku je večkrat govoril, da je brezdomec, deseti brat, da "so mu dali priimeku. Zadevo z materjo in skrbnico je skušal dognati in dokumentirati, pri čemer mu je pomagal tudi škocjanski župnik Janez Jereb, pa menda grofica Auerspergova iz turjaškega gradu, vendar brezuspešno. O Julijinem otroku naj bi se vedelo in govorilo zato, ker je šlo za precejšnjo vsoto denarja. Kogoj se je še posebno spraševal, zakaj je mati Julija umrla, ali ni bila smrt naravna ipd. Zato je župnik Jereb trikrat pisal v Trst za

${ }_{53}$ Mladi Andolšek je takrat spremljal deda, da bi mu. pomagal, ker je ta v Minnesoti, ko se je hotel zaposliti pri bratu Janezu Sevniku (ok. 10 let po njegovem prihodu), izgubil $v$ železniški nesreči obe roki in se je takrat tudi vrnil domov. Ko sta šla $v$ Trst, je bil Andolšek star ok. 5 do 6 let, bilo je nekaj let pred prvo balkansko vojno. Dobro se spominja, da sta podatke o grobu dobila $\mathrm{v}$ župnišču, ki je bilo precej stran od pokopališča; to je ležalo na rahli vzpetini, grob je imel železen in že rjav križ, zato je moral biti po njegovi oceni star vsaj deset let. - H. Močnik, ki je bil prav zaradi rojstnih in smrtnih podatkov o Juliji in rojstnih o njenem sinu $v$ Trstu (Korespondenca, dop. št. 16 in 17), je ugotovil, da bi opisu ustrezalo pokopališče sv. Ane; vendar njegove poizvedbe glede Julije in njene smrti na tržaškem anagrafskem uradu in $\mathrm{v}$ župnijskem arhivu mestne civilne bolnišnice (za leta 1893-97) niso bile uspešne.

${ }_{54}$ Sicer je Janez Sevnik zapustil vse premoženje nečakinji, Jožetovi hčeri Angeli Sevnik. Julija je bila že mrtva, venđar tudi ni želel, da bi se o tem njegovemu otroku kaj zvedelo. Angela je tako odpotovala 1904. (ko je imel Andolšek 1 leto) $\mathrm{v}$ Minnesoto in prevzela Janezovo dediščino, ko je bil ta še živ.

${ }_{55}$ Po tej pripovedi znanimivo je nekrvno sorodstvo Kogoja z njegovo ženo Marijo roj. Podlogar. Andolšek je povedal, da je praded Sevnik, turjaški župan, zapisal posestvo Jožetu Sevniku, ko bo dopolnil 20 let. Neki Gale je porinil pradeda, ko je bil že starejši, po stopnicah s podstrehe in je za posledicami umrl. Gale se je poročil z vdovo po pradedu, mačeho Janeza in Jožeta. Jože je naredil spodaj ob cesti veliko hišo, kamor sta se preselila njegova mačeha in njen mož Gale, sam pa je ostal v očetovi hiši. Njuna hčerka Rezka Gale je kupila nasproti Sevnikovih Koščičarjevo hišo, Gradež št. 5, takrat že vdova po Podlogarju iz Velikega Ločnika. Z njim je imela hčerko Marijo ali Minko Podlogar, šiviljo, poznejšo Kogojevo ženo.

s6 Kogoj naj bi Andolšku večkrat omenjal, da matere ni videl in da je mrtva. 
podatke, menda še posebej o ženski - otrokovi skrbnici, ki naj bi pobrala denar in o ljudeh, ki bi jo poznali, a brez uspeha. ${ }^{57}$ Vendar je Kogoj tudi poslej živel $\mathrm{v}$ prepričanju, da pripada rodu Sevnikovih ${ }^{58}$ in da je seveda v sorodu z Andolškovimi. 59

Če bi $\mathrm{v}$ tem pričevanju Kogojevega znanca mogli videti tudi kakšne spominske spodrsljaje, zamenjave oseb in prenose dejanj na druge osebe, npr. poizvedovanje za materjo Angelo Filippini por. Kogoj in poizvedovanje za pobeglo otrokovo skrbnico, ime Julij Kogoj in ime Julija Sevnik, je osnovna misel vendarle preprosta in očitna, znana naj bi bila tudi Kogoju, po pričevanju o nekaterih sorodstvenih okoliščinah je posredno zavezujoča; se pravi, da je verjetna kot ena varianta Kogojeve življenjske usode.

Sicer se je Andolšek spominjal še nekaterih podrobnosti iz Kogojevega življenja in nekatere lahko preverimo ter pozitivno potrdimo z našo prejšnjo vednostjo. Tako je Kogoj pomagal v Škocjanu pri cerkvenem zboru in pri godbi na pihala, za katero naj bi napisal tudi svojo skladbo. ${ }^{60} \mathrm{Del}$ Crnih mask, zlasti drugo polovico, naj bi komponiral tudi na Gradežu, kjer je imel v svoji hiši klavir, pa tudi pri Sevnikovih na podstrešju v nekdanji spalnici Julije Sevnik. ${ }^{61}$ Spominja se nadalje skladateljeve bolezni. 62

Ce skušamo zaradi nelogičnosti rojstnega leta 1892 in nesprejemljivosti rojstnega datuma 27. IV. 1895 vsaj v mejah Merkùjevih dokazov o smrti Marija Kogoja našo vednost o Kogojevem rodu združiti $\mathrm{z}$ rodovno varianto Sevnik, si nekatere očitne pomanjkljivosti s sklepanjem lažje pojasnimo, vendar naletimo tudi na nove težave. Predvsem lahko zaradi

${ }^{57}$ Andolšek se spominja, da je bil navzoč v župnišču pri Jerebu, ko je prišel tretji odgovor iz Trsta (menda je bilo kmalu po vojni). V spominu mu je ostala Kogojeva jezna reakcija, ko je zvedel za vsebino pisma, ki ga je takoj raztrgal in vrgel proč. Takrat je skladatelj menil, da v Trstu uskrivajo svoj greh" in da ščitijo skrbnico, ki je pobrala denar. Dvomil pa je, da bodo lahko z zadevo se napredovali.

${ }_{58}$ Tako je npr. odnesel $\mathrm{v}$ prvih letih po prvi vojni iz Sevnikove hiše sliko Janeza Sevnika, ki ga je imel za svojega deda in jo obesil v hiši Podlogarjevih. Sliko Julije pa naj bi imel že prej, menda iz Trsta.

${ }^{59}$ Ko je zbolela Andolškova žena pozimi ok. 1. 1937-38, se je že bolni Kogoj močno zavzel, rekoč, da njegovi sorodniki ne smejo umreti. Predlagal je turjaško grofico, ki je bila res zdravnica in kamor so takoj odpeljali bolnico, Kogoja pa so $v$ njegovi vnemi takrat komaj zadržali doma, saj je bil povsem neprimerno oblečen za zimski čas in za globoki sneg.

to Andolšek je povedal, da če ni kdo od pevcev pravilno pel, je Kogoj hitro opazil in ga samega preizkusil; če še vedno ni prav pel, ga je takoj poslal domov. Tudi pri godbi na pihala je takoj ugotovil vsako napako izvajalcev. Skladba, ki naj bi jo napisal (mogoče samo priredil) za ta ansambel, v katerem je igral tudi Andolšek, je imela po njegovi oceni veliko predznakov, takt se je stalno menjal, prav tako dinamika, zato je bila težka za izvedbo.

${ }^{61}$ Andolšek se spominja, da ga je Kogoj prosil, naj mu na evfonij zaigra nekatere odlomke iz opere, češ da se bo pri tem še kaj naučil. Andolšek, ki je dobro igral tudi prima vista, pravi, da je bilo težko, zlasti hitre in močne dinamične spremembe. Iz opere se posebej spominja zbora Gloria. Bil je tudi na premieri Crnih mask v Ljubljanski operi, kjer da so delo sprejeli s ploskanjem, a tudi z žvižgi že med predstavo. 
nedokumentiranosti le ugibamo, ali je in če je, kako je Julijin sin prišel $\mathrm{v}$ skrbništvo $\mathrm{k}$ revnim Kogojevim in ali so bile tu še morebitne druge možnosti, dalje, ali je bila Angela Filippini tista skrbnica, ki je pobegnila z denarjem, ali pa je bila to mogoče kakšna druga oseba? Ali bi lahko po materi Juliji Sevnik dobil ime njen otrok, torej Julij Sevnik, pozneje imenovan Julij Kogoj? Ko je bil Julij Kogoj okoli 1. 1895 v Gorici na zdravljenju, ali je mogoče, da bi tam umrl,63 ali bi bil to lahko celo Julijin sin, pri čemer bi ostalo število živih otrok v Kogojevi družini nespremenjeno? Ali je mogoče, da bi se isto zgodilo tri leta pozneje $v$ tržaški bolnišnici? Ali bi bilo mogoče, da bi $\mathrm{v}$ teh okoliščinah (ob domnevni smrti Julija $\mathrm{v}$ Gorici, brez dokumentacije) prikazali domnevno smrt dojenčka Julija Sevnika kot smrt približno enako starega Marija Kogoja, da bi še dobivali podporo Janeza Sevnika za njegovega vnuka, čeprav bi prav ta Marij $\mathrm{v}$ resnici živel naprej in odrastel v nam znanega skladatelja? Ali je to zadnje sploh možno po Kogojevih izjavah, da je sin Julije Sevnik? V vseh teh in drugih možnih variantah bi kvečjemu lahko računali z bolj logično skladateljevo rojstno letnico nekako med leti 1894 in 1895, ki se ujema z začetkom šolanja $v$ Kanalu 1. 1900, ki pa je seveda točno ne poznamo. Kot nam za to varianto govori sámo Kogojevo mnenje in še morda sklepanje o domnevnem imenu Julij po materi Juliji Sevnik, pa ne vemo, kako je bilo z obiskom "tete ali matere $1.1906,{ }^{64}$ odprto je vprašanje podrobnosti $\mathrm{z}$ bratoma in s sestro po zunanjosti in po značaju, vprašanje glasbe-

\footnotetext{
${ }^{62}$ Prvi znaki naj bi se po Andolšku kazali že v letih po prvi vojni, tako včasih nenavaden, odsoten pogled, sem bi sodili njegovi daljši odhodi z doma, ne da bi domači vedeli kam, siceršnja živčnost (po njegovi presoji dogodek, ko posluša netočno cerkveno petje, vstane in zapusti cerkev). Menda že ok. 1. 1932 ali pozneje nastopijo prehodna obdobja, kakor da ga ızagrne oblak», potem pa je spet vse $v$ redu, mogoče že pozneje vednost, da je hudo bolan, pri čemer naj bi kazal na svojo glavo, zagotovo $\mathrm{v}$ bolezni pa iskanje nekih listin na podstrešju Zevnikovih in zažiganje nekih svojih papirjev in rokopisov.

${ }^{63}$ Poleg Merkùjevih poizvedb, ib., je preverjal možnost bivanja in smrti Julija Kogoja v Gorici $\mathrm{H}$. Močnik; gledal je $\mathrm{v}$ škofijskem arhivu in $\mathrm{v}$ arhivu. Usmiljenih bratov (Korespondenca, dop. št. 12 in 15), vendar ni zasledil nobenih podatkov.

${ }^{64}$ Oseba, ki je takrat obiskala Kogoja, se je predstavila kot teta, bila pa naj bi otrokova mati (gl. Pismeni odgovori Kogojeve sestre Ane, Jež J., op. cit. in Leban K., ib.). Julija Sevnik ni mogla biti, ker je bila takrat že mrtva. Ali je bila to prava teta Angela Sevnik, ki je takrat živela v Minnesoti? Druga dva navedena vira (Jež, Lebanova) omenjata, kakor da bi ta obisk veljal le Mariju Kogoju, ne pa tudi sestri, kar bi se seveda bolj skladalo z obiskom tete, kajpada če si opis $\mathrm{v}$ obeh virih prav razlagamo. Jež J., op. cit., 3, 4, piše, da naj bi mati dala otroku ob tem obisku prstan in svojo fotografijo, ki da ga je spremljala vse življenje. Možno je, da se je prav ta slika ohranila v skladateljevi zapuščini; predstavlja mlajšo žensko osebo, sedečo na stolu in ogrnjeno s kožuhovino. Na fotografiji piše: "Mia mamma Angela Filippini, Vienna XII 1915.» Pisavo je zaradi peresa težko prepoznati, po stilizaciji besedila bi bila lahko Kogojeva na že starejšo sliko ali pozneje do decembra 1915. Po tem bi sklepali, da je skladatelj najbrž še imel v spominu obisk domnevne matere 1. 1906 in da je mislil, da je njegova mati oseba, ki je navedena na njegovem krstnem listu. Ali bi bilo mogoče, da je na sliki Julija Sevnik, česar Kogoj takrat še ne bi vedel? Ali bi bilo možno, da je torej pozneje zvedel, da Angela Filippini vendarle ni njegova mati?
} 
ne nadarjenosti,65 skladnosti $\mathrm{z}$ navedbami, da je skladatelj še pozneje iskal svojo mater in da se mu je ta celo oglasila. ${ }^{66}$

Zaradi pomanjkljivih podatkov vsega tega ni mogoče ali vsaj zaenkrat ni mogoče dognati. Možnosti in možnih domnev - kot pač v življenju, je veliko in preveč, toda premalo trdnih, da bi se bilo mogoče odločiti za eno varianto in kombinacijo. Sklepamo lahko le, da je bil naš skladatelj rojen v Trstu med leti 1894 in 1895 , da je lahko pripadal ali Kogojevi ali Sevnikovi rodbini, pri čemer bi bil lahko ali po očetu ali po materi slovenskega rodu, da je prišel $\mathrm{v}$ Kanal kot sirota najverjetneje $\mathrm{v}$ prvi polovici 1898. leta in da so ga čez dve leti vpisali v tamkajšnjo osnovno šolo, jeseni 1907 pa $v$ goriško gimnazijo, torej $\mathrm{v}$ času, ko se mu je življenju nesporno odvijalo tako, kakor vsaj v obrisih že vemo.

Ker glede na to vprašanje Kogojeve identitete in otroštva ni zadovoljivo pojasnjeno, naj ostane skladatelj v naši glasbi zaenkrat še naprej Marij Kogoj z rojstno letnico 27. IV. 1895 in s pristavkom, da njegova identiteta in $\mathrm{s}$ tem točen datum rojstva še nista dognana.

\section{SUMMARY}

The question of the identity of the Slovene composer Marij Kogoj has remained open for a long time. Only recently P. Merkù's research revealed that the composer, hitherto known as Marij Kogoj, born April 27, 1895, died as an eightmonth old baby - whereas his brother Julij, born September 20, 1892, remained alive. Evidence has been found that Julij is in fact the composer, only that he was renamed after the dead Marij and on that occasion his brother's, i. e. Marij's date of birth - 1895 - had been entered into the registrar.

This, in itself, appears to solve the question of the composer's identity. Difficulties, however, appear when the new date of birth - 1892 - is to be brought into agreement with the composer's other biographic data, especially those regarding his schooling formerly in agreement with the old date. The present research seeks to establish relevant comparisons.

The checking was directed at the composer's documents on his attending the Gorizia Gymnasium and the Vienna Akademie für Musik und darstellende Kunst, where the data-tolerance is even greater. Even more clearly came the new date of birth out in the course of examining the data about the composer's elementary education, collected by the author from oral evidence of Kogoj's schoolfellows and concluded from the fact that three of the Kogoj children-orphans came to Kanal,

${ }_{65}$ Vemo, da je Angela Fillippini, potem ko je zapustila otroke, »odšla z neko operetno družbo, kjer je pela v zboru (Pismeni odgovori Kogojeve sestre Ane, ib.; gl. tudi Merkù P., ib., 53); se pravi, da je morala biti muzikalna. Andolšeik pa navaja, da sta brata Janez in Jože Sevnik igrala harmoniko in da sta te instrumente tudi izdelovala, poleg njega samega kot instrumentalista in njegove hčerke, ki uči glasbo, pa je profesorica glasbe tudi hčerka Angele Sevnik. Očitno sta bili torej obe rodbini muzikalni.

${ }_{66}$ Jež J., op. cit., 3, 4. Kogoju naj bi se oglasila dvakrat, zadnjič iz São Paula v Braziliji, a obakrat le s pošiljko denarja. Pozneje naj bi jo skladatelj iskal še prek švicarskega Rdečega križa, vendar brez uspeha. Vidmar navaja drugače (Vidmar J., ib., 769). Kogoj naj bi mu pravil, da je odšla v Egipt in zatem menda v Chicago, kjer je po Kogojevem mnenju spet izginila. Kljub različnosti navedb $\mathrm{v}$ obeh virih je odtod razvidno, da naj bi Kogoj iskal mater in ne skrbnico. 
after they had been - after their father's death - deserted by their mother. It appears unlikely that the boy's guardians should not have sent him to school until after he was eight years old (considering that compulsory education started with the age of six), especially because the orphans seem to have arrived to Kanal from Triest two years earlier.

Considering other evidence as well as the fact that the composer entered elementary school in the autumm of 1900 , the only conclusion feasible is that the composer was born at a later date, sometime in the years 1894-95.

Another unclear point is the baptism certificate issued in 1906. The hitherto existing Julij received a certificate reading the name of Marij Kogoj with the date 1895; the argument of the issuer, the Parochial Archives of St. Anthony of Padova in Triest, was that Julij is dead and that Marij is still alive. The guardians at Kanal had thus renamed Julij into Marij. All this being rather unusual, yet another fact comes as a surprise: the birth and death books in the same archives give proof to the opposite: Julij is alive, whereas Marij is dead.

Because of deficient sources it has been necessary to leave the question of the exact date and the identity of the composer open. The most recently collected information from oral communication strongly suggest the possibility that the composer did not belong to the Kogoj family at all but to the Sevnik family from Gradež near Turjak, where the composer's wife came from. The documentation is, unfortunately, more or less destroyed. It appears, however, that the composer was aware of the whole issue and that he himself regarded himself as belonging to the Sevnik family. The author of the article has tried, but with no success so far, to document the whole matter. His attempt at confronting what is known about Kogoj with the Sevnik variant has solved some unlogical points maintained so far but has, on the other hand, opened new problems.

All things considered the author suggests that the composer should for the time being remain Marij Kogoj, with the birth-data April 27, 1895, with the postscript, that neither his identity nor the exact date of birth have been hitherto difinitely established. 